\title{
The influence of motivations on the image of non-hotel tourist accommodation offering
}

\author{
Sergio Moreno-Gil* \\ Institute of Tourism and \\ Sustainable Development Economics (TiDES), \\ Business and Tourism Faculty, \\ University of Las Palmas de Gran Canaria, \\ Building C1.11. 35017, Las Palmas de Gran Canaria, Spain \\ Fax: 0034928457303 \\ E-mail: smoreno@dede.ulpgc.es \\ *Corresponding author
}

\section{Josefa D. Martín-Santana}

Business and Tourism Faculty,

University of Las Palmas de Gran Canaria,

Building C1.11. 35017, Las Palmas de Gran Canaria, Spain

Fax: 0034928451789

E-mail: jmartin@dede.ulpgc.es

\begin{abstract}
Accommodation image has been scarcely researched in the literature and is worthy of further investigation. Moreover, to date, no previous studies have analysed non-hotel accommodation image, even when this type of accommodation is the primary offer of some tourist destinations and plays a critical role in the overall perception of the destination. This research aims for a deeper understanding of accommodation image. Thus, after an extensive review of the literature, the aim is to obtain the main dimensions of cognitive image that characterise this product and to analyse how these dimensions affect the overall accommodation image. Finally, this research analyses the influence of motivations on the formation of accommodation image. Tourists motivated by 'fun and prestige' evaluate accommodation image more positively than tourists motivated by 'relaxation, knowledge, and social interaction'. The study highlights the academic and practical implications of these findings.
\end{abstract}

Keywords: accommodation image; motivations; non-hotel accommodation product; apartments; bungalows; marketing; hospitality.

Reference to this paper should be made as follows: Moreno-Gil, S. and Martín-Santana, J.D. (2013) 'The influence of motivations on the image of non-hotel tourist accommodation offering', Int. J. Tourism Policy, Vol. 5, Nos. $1 / 2$, pp.59-81.

Biographical notes: Sergio Moreno-Gil is the Managing Director of the Tourism and Sustainable Development Research Centre at Las Palmas de Gran Canaria University, and the Director of Institutional Relations at the UNESCO Chair of Tourism Planning and Sustainable Development. He cooperates with several companies and destinations in a consulting capacity and teaches in several universities. He has also published some books and articles in journals such as Annals of Tourism Research, Journal of Travel Research, Tourism 
Management, International Journal of Tourism Research, Journal of Tourism and Leisure Marketing, Journal of Vacation Marketing, etc. His research interests are image, destination marketing, loyalty and segmenting.

Josefa D. Martín-Santana is a Full Professor of Marketing at Las Palmas de Gran Canaria University and has developed different responsibilities in the marketing department, co-Director of the $\mathrm{PhD}$ programme, co-Director of the marketing master, etc. She cooperates with several companies and universities. She has also published some books and articles in journals such as Annals of Tourism Research, Tourism Management, European Journal of Marketing, Journal of Advertising, etc. Her research interests are advertising, promotion, image and marketing.

This paper is a revised and expanded version of a paper entitled 'Understanding the Image of non-hotel tourist accommodation offer' presented at the First International Conference on Emerging Research Paradigms in Business and Social Sciences (ERPBSS), Middlesex University Dubai, United Arab Emirates, 22-24 November 2011.

\section{Introduction}

Although accommodation image is an important topic for both the hospitality industry and destination marketing organisations (DMOs), it has not been widely analysed by researchers. Despite the importance of non-hotel accommodation in many destinations, there are no reported studies on this subject. Few analyses focus on accommodation image as a product, as this issue is generally only important for the tourism industry when analysed from a general and systemic perspective. Thus, it does not attract the attention of the hospitality industry as individual enterprises focus on their private businesses and topics such as branding, positioning, or quality, which are indeed extensively analysed in the literature. There are several research studies on motivation in the tourism sector, given its relevance in the study of tourist behaviour. In this line, Esper and Rateike (2010) state that within the tourism field, motivations are an important factor in the decision-making process of travel and determining where to go. Thus, it is necessary to know if motivations influence the image to try to create a feeling of necessity and, subsequently, an action. However, there is no reported research on how motivation influences accommodation image. Accommodation image is also of great relevance for DMOs since the tourist's overall perception of the destination reflects the total experience of the trip (Murphy et al., 2000; Andriotis, 2008). DMOs and the hospitality industry would benefit from a better understanding of accommodation image, its dimensions, and how these dimensions affect overall accommodation image. This information would help both the DMOs and the hospitality industry improve their performance. Moreover, obtaining these general dimensions of image could enable the comparative transnational and cultural study of this topic, as the literature on hospitality has mainly focused on the professional world and lacks a deeper vision (Morrison, 2002).

Despite accommodation image being a key element for the success of the accommodation (LeBlanc and Nguyen, 1996; Zeithaml and Bitner, 1996; Choi and Chu, 1999) and the destination, there is little research on it. The literature has favoured other 
approaches, such as quality rather than image (Laroche and Parsa, 2000; Chen et al., 2001), and no studies have analysed the non-hotel accommodation image. Furthermore, this study examines the image of the non-hotel accommodation offering by first analysing the theoretical dimensions that compose the functional image, empirically testing those dimensions, and identifying which dimensions have greater influence on overall image. Finally, this research analyses how motivations influence the formation of non-hotel accommodation image. 'Non-hotel accommodation' has been defined in this study as the offering that integrates any commercial tourist accommodation offering except hotels. In this case, this offering includes apartments, bungalows, and villas.

\section{Literature review}

The environment of the hospitality industry is too dynamic and complex and there is a need to search for new strategies and guidelines (Brownell, 2003), and academic research involves abstracting from specific contextual problems to develop a generally applicable theory to provide a better understanding of the situation (Piccoli and Wagner, 2003). In this regard, aspects such as segmentation, positioning, and image are amongst the most important issues for the hospitality industry (Morgan and Dev, 1994) and require more attention from the literature.

Image is a key factor that influences decisions made by the tourist, as their internal reality drives them to make choices (Huang et al., 2009). Positive image is a green card for success. In this respect, destinations and hotels with stronger and more positive images are more likely to be chosen in the tourist's travel decision process (Hunt, 1975). Additionally, motivations are a key component to understanding the tourist's final decision when choosing accommodation. Thus, understanding whether different motivations affect accommodation image can shed some light on the process of accommodation image formation.

\subsection{Accommodation image}

Image is a mixture of positive and negative perceptions that represent the reality that individuals face when they choose a destination (Okumus and Yasin, 2009). Only when the positive image outweighs the negative will the potential tourist make that choice (Milman and Pizan, 1995; Chen and Kerstetter, 1999; Wagner et al., 2009). Following various authors (Echtner and Ritchie, 1991, 1993; Baloglu and McCleary, 1999, 2001; Beerli and Martín, 2004), there are three main different approaches to contextualise image:

1 from a perceptual or cognitive perspective by evaluating the attributes (i.e., the beliefs that individuals have about the product)

2 from an affective point of view, on the basis of the emotional feelings aroused by the offering 
3 from an overall approach or general evaluation of the product, formed by both the affective and the cognitive images.

Based on the review of the literature, accommodation image can be defined as "the subjective representation of the set of beliefs, impressions, information, and attitudes regarding the accommodation."

Accommodation image is a major element in company success since it plays a leading role in the choice of a hotel (Lewis, 1984, 1985; Chen and Hsu, 2000) and is even more important in the case of vacation hotels (Dubé and Renaghan, 2000). Furthermore, product image is of great importance in capturing new customers, increasing market share, and enabling a suitable positioning of the product (Roth, 1995; Chen et al., 2001). Accommodation image is also vital to increase customer satisfaction (Mazanec, 1995; Pizam and Milman, 1993) and loyalty to the accommodation (Kandampully and Suhartanto, 2000, 2003; Hunt, 1975; Ostrowsky et al., 1993; Bhote, 1996; Heung et al., 1996).

However, unlike destination image, accommodation image has hardly been addressed in the literature (LeBlanc and Nguyen, 1996; Kandampully and Suhartanto, 2000; Chen et al., 2001; Barsky and Nash, 2002), which has favoured other perspectives such as satisfaction (Barsky and Labagh, 1992; Heide et al., 1999; Heung, 2000; Choi and Chu, 2001) and quality (Getty and Thompson, 1994; Yucelt and Marcella, 1995; Min and Min, 1996; Ekinci et al., 1998; Qu and Tsang, 1998; Choi and Chu, 1999; Mei et al., 1999; Tsang and Qu, 2000; Min et al., 2002; Ekinci et al., 2003).

\subsection{Accommodation image dimensions and attributes}

Measuring accommodation image is extremely complicated because of the difficulty to adapt the language to the multiple peculiarities of accommodation. Chen et al. (2001) stress the need to define and refine specific scales of accommodation perception because, despite the attention paid to customer perception of hotel attributes, there has been little progress in the development of precise scales (Getty and Thompson, 1994). However, this is a complicated task as it requires the inclusion of an extensively high number of items in the measurement (Headley and Millar, 1993; Taylor and Cronin, 1994; Litaca et al., 1995). Although there is a broad consensus amongst researchers on the multidimensional nature of the customer's perception of the accommodation product, there is no such consensus in terms of number or content regarding which dimensions and attributes define that perception. There are several different approaches in the literature where, apart from the satisfaction perspective, those of brand and quality predominate. Brand and quality approaches share a great part of their structure without there being any unanimity about which is more suitable to evaluate consumer perception (Ekinci, 2002). The literature has provided large groups of attributes in an attempt to identify the specific microdimensions of accommodation. However, they are the result of studies undertaken in hotels, mainly in the USA and Hong Kong, Asia's most popular vacation destination for 30 years (Bailey, 1995), which greatly limits their universality. Studies undertaken in other destinations are less common, and those taken in non-hotel accommodations are the exception in the literature.

Both the number and the content of the dimensions and attributes used in the literature are very high and heterogeneous. Lewis (1984) uses 66 attributes to evaluate the perceptions of business and leisure customers. A study conducted by Lockwood et al. 
(1992) by means of interviews with 47 customers identifies 564 separate attributes that define the quality of a budget hotel and groups them into 25 final dimensions that represent $92 \%$ of the answers obtained. In descending order of importance, the resulting dimensions are as follows: perceived price, general standard, cleanliness, friendliness, food quality, hotel style, service quality, décor and maintenance, concept of accommodations, comfort, location, restaurant style, leisure facilities, room furniture and fittings, category, telephone, temperature, management, children's facilities, security and consistency, bar, noise, social interaction, and security.

Later studies, such as Callan's (1994), have attempted to establish a framework of hotel attributes to be used in research based on the criteria customers use when choosing a hotel. After reviewing 45 articles, Callan determines an initial group of 139 service attributes, refined and enlarged by qualitative analyses, to obtain a final group of 166 heterogeneous attributes, finally grouped into 10 dimensions - namely, location and image, additional services, value for money, recreational services, service supplier, room (tangibles), other tangibles, safety, access, and competence. However, LeBlanc and Nguyen (1996) identify the following five dimensions of accommodation image: personal contact, physical atmosphere, quality of service, accessibility, and corporate identity. In conclusion, the number of identified dimensions ranges from a high number (e.g., McClearly et al., 1998, with 13 dimensions) to a small one (e.g., Min and Min, 1996, identify only two dimensions in customer perception - namely, room and front office). However, the most common result is between five and eight dimensions. To mention some examples, the studies of Choi and Chu (1999) identify seven dimensions, Dubé and Renaghan (1999, 2000) six, Chu and Choi (2000) six, Heung (2000) eight, and Chu (2002) five.

An analysis of a representative, but not exhaustive, selection of studies leads to the following conclusion: most studies use multi-attribute scales, whilst a minority use qualitative analyses, with a composition rather than a decomposition approach, focusing on accommodation attributes from the consumer perspective (Callan, 1994; Bowen and Sparks, 1998; Dubais, 1999; Chen et al., 2001).

Thus, the main attributes the customer considers when forming his/her image of the non-hotel accommodation can be grouped into seven specific dimensions and several attributes that include tangible and intangible elements (see Appendix). This will facilitate the conduct of comparative studies in different accommodations and geographical areas by simply adapting the different attributes to the peculiarities of the accommodations. The seven dimensions are as follows:

1 the establishment in general

2 primary services

3 secondary services

4 accommodation unit (i.e., apartment or bungalow)

5 service personnel

6 price

7 food and beverage offering $(\mathrm{F}+\mathrm{B})$ (only applicable when the non-hotel accommodation offers restaurant or cafeteria service). 
In any case, the number and content of the attributes can vary depending on the destination where the accommodation is located. These dimensions, on the one hand, compose the cognitive image - that is, the perceptual or rational perspective in evaluating the attributes (i.e., the beliefs that individuals have about the product).

On the other hand, there is no consensus on the possible influence of each dimension of the cognitive image on the overall, holistic image of the accommodation. Regarding the importance that customers attach to the different attributes, various authors such as $\mathrm{Hu}$ and Ritchie (1993) and Chen and Hsu (2000) argue that some attributes have universal importance, whilst others state that each dimension has an importance related to the activity under study (Mackay and Crompton, 1990) or the specific characteristics of the tourist.

\subsection{Motivations}

Motivations give rise to different behaviours in the choice of destination and touristic products (Correia et al., 2009). Motivations are defined as a state of mind that adequately disposes tourists to travel or as explanations given by tourists for the decision to travel (Dann, 1981). As an explanatory factor for behaviour, motivation enables a better understanding of the tourists' real expectations, needs, and perceptions (Mansfeld, 1992). Following Fodness (1994), the basic motivation theory describes a dynamic process of internal psychological factors (needs, wants, and goals) that generate an uncomfortable level of tensions within the individuals' minds and bodies. These inner needs and the resulting tension lead to actions designed to release that tension, which thereby satisfy the needs. Thus, the decision of individuals to travel may be triggered by different reasons, and these reasons can be interpreted as the drive to release tension and are results of physiological and psychological needs.

Identifying tourist motivations is a key element in marketing because of their influence on the process of choosing a destination (Beerli and Martín, 2004) and on their behaviour. However, this identification poses some difficulties as the buying process is not triggered by only one motive; the process involves several interrelated motives that also vary according to the time and the individual (Pearce, 1993; Valls, 1996).

In academic literature on tourism motivation, several studies have attempted to create a list of reasons or motives that drive individuals to travel. Gray (1979) proposed a simplified travel motivation theory based on two main determinants: 'wanderlust' and 'sunlust'. Gray defines 'wanderlust' as the desire to travel to another destination, experience new feelings, and escape. 'Sunlust' characterises holidays that are motivated by the desire to experience different amenities that cannot be found in the environment where the individual normally lives. In line with this, Moutinho (1987) also considers there are two main travel motivations: general and specific. General motivations include, amongst others, educational and cultural factors, relaxation, adventure and pleasure, health and recreation, ethnic aspects and family, and social and competitive factors. The literature includes a wide range of general motivations and multiple classifications. From this point of view, specific motivations include images based on knowledge, the opinion of family and friends, information obtained directly or indirectly through mass media, travel agencies, tour operators, etc.

Another classification of motivations includes push and pull factors. For instance, Dann (1981) and Goossens (2000) consider that motivations are related to the needs and aims of individuals (push factors), whilst pull factors relate to the marketing stimuli that 
attract tourists based on the attributes of the destination and its main tourist sites. Both factors contain a motivational element, with emotion being the psychological factor that connects them. Tourists are drawn by their (emotional) needs, and they are pulled by the destination's (emotional) benefits (Dann, 1981). Gnoth (1997) argues that push factors are internally generated drivers that cause the tourist to search for signs in objects, situations, and events to reduce uncertainty. In turn, pull factors are generated to provide a better understanding of the destination's attributes and reinforce motivations or push factors.

The literature contains several studies that focus on the specific motivations that make an individual want to travel. Dann (1977), based on an empirical study on a visitor's attitude towards Barbados, identifies two types of basic inner motivations that drive individuals to travel:

1 motivations related to the desire to overcome a feeling of isolation and get away from the daily routine

2 motivations derived from the need for social recognition associated with travel.

In turn, Fodness (1994), following the functional diagram developed by Katz in 1960 and basing on a qualitative study, designed a 65 -item scale of travel motivations that can be grouped into four basic functions:

1 knowledge: includes cultural motives regarding experiences in other cultures and visiting places of current or historical interest

2 utilitarian: linked to the idea of escaping daily routine, trying to reduce the consequences of everyday responsibilities, and looking for rewarding leisure activities

3 social: motives related to social interaction with relatives or other people that intensify interpersonal relationships

4 self-expressive: includes self-esteem and ego enhancement so that individuals can express values they consider important.

Fodness subsequently reduced the scale to 20 items. This scale groups all of the main travel motivations and has been widely used in previous studies, confirming its validity.

After addressing the conceptualisation and typology of travel motivations, it is necessary to analyse the role of motivations on accommodation image. Several studies on travel destinations have highlighted the clear influence of motivations on image (Lee, 2009; Esper and Rateike, 2010). In the same way, authors such as Baloglu (1997), Dann (1996), and San Martin and Rodríguez del Bosque (2008) explain that motivations have a great influence on the affective component of the image; and Baloglu and McCleary (1999) suggest a moderate relationship between the tourist motivations and the affective component and that motivations are also related to the overall image. However, Chen and Chen (2010) state the need to analyse motivations and their relationship with accommodation image as it is an aspect that should be studied in greater depth in the literature. In line with this, Esper and Rateike (2010) state that tourists' motivations must be taken into account when promoting the destination and segmenting the target market because these are of great importance when making travel decisions. 


\section{Methodology}

The questionnaire was composed of three parts:

1 general information about the type of accommodation and typology (e.g., 'Did you stay in an apartment, bungalow, or villa during these holidays?'), category, etc.

2 accommodation image, destination image, and motivations

3 tourists behaviour (days in the destination, party group, etc.) and sociodemographic data.

To measure the perceived functional accommodation image, 51 attributes were initially selected based on those suggested in the literature. After 10 in-depth interviews with different experts and practitioners, we developed a scale that included the different dimensions of non-hotel accommodation image and that contained 42 attributes. After applying an initial pretest that included personal interviews to a sample of 22 tourists from different nationalities, we obtained a 32-item, 7-point Likert scale related to the main seven dimensions described in literature:

1 the establishment in general (location, safety and security, peace and quiet, good reputation of accommodation, cleanliness of accommodation, accommodation size, and accommodation architecture)

2 primary services (24-hour reception service, minimarket, pool condition and maintenance, solarium, size and maintenance of gardens, and private bungalow garden)

3 secondary services (entertainment in house, nightlife in house, health club and spa centre), facilities for children (babysitter, children menu, playground), sports (tennis, squash, paddle, volleyball, gym, golf, windsurfing, etc.), services to contract (rent a car, excursions, etc.)

4 accommodation unit - that is, apartment or bungalow [apartment/bungalow overall, apartment/bungalow size, apartment/bungalow's kitchen, kitchen facilities (electrical appliances), apartment's/bungalow's view, well-maintained furnishings, apartments/bungalows are clean and well maintained, air-conditioning, TV with channels in your mother tongue, bathroom overall, bathroom size, bathroom cleanliness, bathroom furniture, and bathroom amenities]

5 service personnel (service speed and efficiency and service friendliness and professionalism)

6 price (low or good prices, discounts, and frequent-guest programme)

7 food and beverage offering (food and beverages overall, food and beverages quality, food and beverages variety, and food and beverages prices).

That scale was then translated into several languages, and each version was pretested. After the pretest, no changes were made to the scales. 
The overall accommodation image was measured using a single-item 7-point Likert scale. (The scale from 1 to 7 , from a general point of view, indicates how positive or negative the image you have of the accommodation that you stayed in during this holiday is. Bear in mind that 1 indicates very negative and 7 very positive.) Finally, tourist motivations were measured using the different classified motives based on the typology of basic functions suggested by Fodness (1994), with a 19-item, 7-point Likert scale suitable to measure motivations because of its multifunctional nature (Pyo et al., 1989). Following Goossens (2000), this is an easy-to-administer self-reported scale that relates tourism to motivations and functional theorists like Crompton (1979) and Moutinho (1987).

The geographical setting of the empirical research was Gran Canaria (Spain). The universe comprised leisure tourists aged 18 and above who stayed in non-hotel accommodation establishments. The individuals came from the destination's main sources of tourists - namely, the UK, Germany, Spain, Scandinavia, the Netherlands, and Ireland, nations that account for $86.3 \%$ of the island's total tourists. The individuals chosen for the sample were selected at the departure terminal of the Gran Canaria Airport. The final sample includes 312 participants. Stratified random sampling guaranteed proportional stratification according to the dimensions of nationality, age, and gender.

\section{Analysis of results}

The sample of the study comprises male and female customers in similar proportions (50\% each). There is a normal distribution amongst age intervals, with the age-group from 25 to 34 being the largest. In terms of education level and social class, $45 \%$ of the participants were university graduates, and $49 \%$ belonged to the middle class. There was a predominance of tourists from Great Britain (29\%) and Germany (28\%), as these countries are the main sources of tourists in the Canary Islands.

\subsection{Analysis of scales, dimensions, and reliability}

One of the purposes of the study was to identify the dimensions that determine the cognitive image of non-hotel accommodation and the type of motivations that drove tourists to choose Gran Canaria as their holiday destination. The scales had to be reduced or refined to determine the most relevant dimensions of both constructs. Out of the wide variety of multivariate statistical techniques, factor analysis is the most common procedure to obtain dimensions (Pearce, 1982; Fakeye and Crompton, 1991; Echtner and Ritchie, 1993; Walmsley and Jenkins, 1993). Thus, an exploratory factor analysis with varimax rotation was performed to refine the scales of cognitive image of non-hotel accommodation and motivations and to examine the suitability of the dimensions.

The final result does not include all of the initial items of the scale of the cognitive image of the non-hotel accommodation offering (see Table 1). Some items had to be eliminated (accommodation architecture, bathroom size, apartment/bungalow size, air-conditioning, location, and peace and quiet), as they showed communalities or factorial loads far below 0.5 or had similar values in more than one factor; this made the interpretation of the factors difficult and gave rise to lower levels of explained variance. 
The overall reliability level obtained is satisfactory, with a Cronbach's alpha of 0.9133 and Cronbach's alpha values ranging from 0.71 to 0.91 for the different factors.

Seven clearly defined dimensions have been extracted from the exploratory factor analysis. We have labelled these dimensions 'secondary services' (IACC1), 'food and beverage' (IACC2), 'personnel and cleanliness' (IACC3), 'kitchen' (IACC4), 'outdoor areas' (IACC5), 'primary services' (IACC6), and 'price' (IACC7). First, the results of the factor analysis can be deemed satisfactory since they jointly explain $70.35 \%$ of variance, and individually, each dimension explains between $6.66 \%$ and $13.89 \%$, all with eigenvalues above 1 . Second, the correlations between the factors and the different items, expressed by means of factorial loads, are highly significant insofar as they all have levels above 0.5 (Hair et al., 1987). Third, communalities determined that the proportions of the explained variance of each item are high, as more than half of the variability of the answers was explained in all cases.

Table 1 Factor analysis of accommodation image

\begin{tabular}{|c|c|c|c|c|c|c|c|c|}
\hline Variables & COM. & $I A C C 1$ & $I A C C 2$ & $I A C C 3$ & $I A C C 4$ & IACC 5 & IACC6 & $I A C C 7$ \\
\hline Entertainment i & 0.719 & 0.761 & 0.167 & 0.099 & 0.050 & 0.106 & 0.247 & 0.191 \\
\hline $\begin{array}{l}\text { Health club and spa } \\
\text { centre }\end{array}$ & 0.713 & 0.759 & -0.049 & 0.071 & 0.221 & 0.262 & 0.110 & 0.061 \\
\hline Nightlife in house & 0.732 & 0.754 & 0.217 & -0.053 & 0.044 & 0.161 & 0.247 & 0.155 \\
\hline $\begin{array}{l}\text { Facilities for children: } \\
\text { babysitting, children } \\
\text { menu, playground }\end{array}$ & 0.576 & 0.718 & 0.069 & 0.082 & 0.210 & 0.037 & -0.042 & 0.059 \\
\hline $\begin{array}{l}\text { Sports: tennis, squash, } \\
\text { paddle, volleyball, gym, } \\
\text { golf, windsurfing, etc. }\end{array}$ & 0.593 & 0.711 & 0.129 & 0.075 & 0.036 & 0.254 & -0.187 & -0.094 \\
\hline $\begin{array}{l}\text { Food and beverages } \\
\text { quality }\end{array}$ & 0.848 & 0.089 & 0.872 & 0.232 & 0.092 & 0.093 & 0.084 & 0.034 \\
\hline $\begin{array}{l}\text { Food and beverages } \\
\text { variety }\end{array}$ & 0.852 & 0.145 & 0.864 & 0.237 & 0.070 & 0.027 & 0.115 & 0.099 \\
\hline $\begin{array}{l}\text { Food and beverages } \\
\text { prices }\end{array}$ & 0.811 & 0.147 & 0.815 & 0.163 & 0.087 & 0.083 & 0.092 & 0.275 \\
\hline $\begin{array}{l}\text { Food and beverages } \\
\text { overall }\end{array}$ & 0.716 & 0.357 & 0.660 & 0.345 & 0.111 & -0.061 & 0.145 & 0.012 \\
\hline $\begin{array}{l}\text { Service friendliness and } \\
\text { professionalism }\end{array}$ & 0.763 & 0.112 & 0.164 & 0.823 & 0.098 & 0.159 & 0.039 & 0.095 \\
\hline $\begin{array}{l}\text { Service speed and } \\
\text { efficiency }\end{array}$ & 0.678 & 0.226 & 0.110 & 0.761 & 0.072 & 0.094 & -0.078 & 0.115 \\
\hline $\begin{array}{l}\text { Apartments/bungalows } \\
\text { are clean and well } \\
\text { maintained }\end{array}$ & 0.717 & -0.042 & 0.356 & 0.645 & 0.242 & 0.068 & 0.331 & 0.010 \\
\hline $\begin{array}{l}\text { Cleanliness of } \\
\text { accommodation }\end{array}$ & 0.648 & -0.103 & 0.284 & 0.643 & 0.126 & -0.051 & 0.276 & 0.221 \\
\hline Bathroom cleanliness & 0.669 & -0.117 & 0.437 & 0.625 & 0.168 & -0.089 & 0.194 & 0.092 \\
\hline
\end{tabular}


Table 1 Factor analysis of accommodation image (continued)

\begin{tabular}{|c|c|c|c|c|c|c|c|c|}
\hline Variables & COM. & $I A C C 1$ & $I A C C 2$ & $I A C C 3$ & $I A C C 4$ & $I A C C 5$ & IACC6 & $I A C C 7$ \\
\hline $\begin{array}{l}\text { Kitchen facilities } \\
\text { (electrical appliances, etc.) }\end{array}$ & 0.753 & 0.232 & -0.085 & 0.130 & 0.784 & -0.026 & 0.258 & 0.020 \\
\hline $\begin{array}{l}\text { Apartment/bungalow's } \\
\text { kitchen }\end{array}$ & 0.683 & 0.195 & 0.116 & 0.159 & 0.703 & 0.117 & 0.148 & 0.276 \\
\hline $\begin{array}{l}\text { Apartment/bungalow } \\
\text { view }\end{array}$ & 0.623 & 0.069 & 0.253 & 0.187 & 0.673 & 0.257 & 0.015 & 0.015 \\
\hline $\begin{array}{l}\text { Size and maintenance of } \\
\text { gardens }\end{array}$ & 0.758 & 0.253 & 0.164 & 0.155 & 0.124 & 0.786 & 0.100 & 0.080 \\
\hline Private bungalow garden & 0.733 & 0.189 & -0.094 & 0.076 & 0.242 & 0.782 & 0.062 & 0.093 \\
\hline Solarium & 0.661 & 0.408 & 0.171 & 0.033 & -0.141 & 0.591 & 0.180 & 0.251 \\
\hline Minimarket & 0.776 & 0.157 & 0.113 & 0.025 & 0.168 & 0.060 & 0.840 & 0.036 \\
\hline $\begin{array}{l}\text { 24-hour reception } \\
\text { service }\end{array}$ & 0.599 & 0.361 & 0.118 & 0.347 & 0.115 & 0.122 & 0.552 & 0.041 \\
\hline $\begin{array}{l}\text { Pool condition and } \\
\text { maintenance }\end{array}$ & 0.528 & 0.048 & 0.319 & 0.385 & 0.124 & 0.227 & 0.455 & -0.043 \\
\hline Accommodation size & 0.522 & 0.124 & 0.161 & 0.351 & 0.321 & 0.187 & 0.433 & 0.178 \\
\hline Low or good prices & 0.824 & 0.036 & 0.141 & 0.350 & 0.061 & 0.084 & 0.106 & 0.811 \\
\hline Discounts & 0.795 & 0.255 & 0.155 & 0.041 & 0.181 & 0.115 & -0.019 & 0.811 \\
\hline Eigenvalue & & 1.087 & 3.172 & 1.752 & 1.366 & 1.234 & 1.031 & 1.005 \\
\hline $\begin{array}{l}\% \text { partial explained } \\
\text { variance }\end{array}$ & & 13.897 & 13.405 & 12.994 & 8.081 & 7.742 & 7.567 & 6.663 \\
\hline $\begin{array}{l}\% \text { total explained } \\
\text { variance }\end{array}$ & 70.349 & & & & & & & \\
\hline Cronbach's alpha factors & & 0.8524 & 0.9157 & 0.8384 & 0.7568 & 0.7402 & 0.7318 & 0.7147 \\
\hline Cronbach's alpha total & 0.9133 & & & & & & & \\
\hline KMO: & 0.870 & & & & & & & \\
\hline Bartlett's sphericity: & $3,883.3$ & & & & & & & \\
\hline Significance: & 0.000 & & & & & & & \\
\hline
\end{tabular}

The first dimension refers to the secondary services offered by the accommodation and all its items have similar weights. In the dimension food and beverage, the weight is also distributed equally between quality, variety, and price of the offering. The third factor is defined first by service personnel and second by general and accommodation unit cleanliness. This dimension, which contains solely intangible elements, groups cleanliness with personnel; tourists usually spend more time in the apartment or bungalow, so cleaning personnel and customers are in close contact in this type of establishment. That is why both aspects have been combined. The fourth dimension defines both the kitchen, a fundamental element in the accommodation unit of a non-hotel establishment, and the views from the accommodation unit. The fifth dimension includes the outdoor areas of the accommodation, specifically the gardens and solarium. The sixth 
dimension defines the primary services of non-hotel accommodation and covers the reception and minimarket, whilst it also includes the swimming pool and size of accommodation unit, albeit with a very low loading that might advise its elimination. The final dimension groups price and discounts.

The dimensions obtained largely coincide with those initially proposed (e.g., price, restaurant, secondary services), although there are some differences. The dimension of service personnel includes cleanliness, which shows the importance of the housekeeping personnel in this type of establishment in which there is very direct and frequent contact. The kitchen plays a leading role in the accommodation unit since it is often the reason why the tourist chooses this type of establishment, perceived as a dimension in itself. Finally, the dimension of the establishment in general was not obtained in the analysis, but it was replaced by outdoor areas, which constitute the generic image of the establishment.

Following the previous validation criteria, an exploratory factor analysis with varimax rotation was performed on the variables that define tourist motivations. The results show five factors with eigenvalues above 1 that explain $75.67 \%$ of total variance. Results in Table 2 show five clearly differentiated dimensions that have been labelled as 'culture' (MOT1), 'status and social influence' (MOT2), 'relaxation' (MOT3), 'adventure' (MOT4), and 'social interaction' (MOT5). Similarly, it shows that

1 the results of the factor analysis are satisfactory as they jointly explain $75.67 \%$ of variance, and individually, each dimension explains between $18.48 \%$ and $11.20 \%$, all with eigenvalues above 1

2 correlations between the factors and different items, expressed by the means of factorial loads, are highly significant, as they all have values above 0.5 (Hair et al., 1987)

3 communalities determined that the proportions of the explained variance of each item are high, as more than half of the variability of the answers was explained in all cases.

Table 2 Factor analysis of motivations

\begin{tabular}{|c|c|c|c|c|c|c|}
\hline Variables & COM. & MOTI1 & MOTI2 & MOTI3 & MOTI4 & MOTI5 \\
\hline Cultural enrichment & 0.866 & 0.890 & 0.083 & 0.059 & -0.072 & 0.186 \\
\hline $\begin{array}{l}\text { Know different cultures and } \\
\text { lifestyles }\end{array}$ & 0.835 & 0.880 & 0.095 & 0.122 & 0.023 & 0.213 \\
\hline Cultural events & 0.772 & 0.818 & 0.228 & 0.298 & -0.045 & 0.187 \\
\hline $\begin{array}{l}\text { Discover new and different } \\
\text { places }\end{array}$ & 0.536 & 0.654 & 0.223 & 0.045 & 0.856 & 0.843 \\
\hline $\begin{array}{l}\text { Tell friends about my travel } \\
\text { experiences }\end{array}$ & 0.628 & 0.122 & 0.778 & -0.096 & 0.148 & 0.298 \\
\hline $\begin{array}{l}\text { Go to places friends have } \\
\text { visited }\end{array}$ & 0.741 & 0.122 & 0.747 & 0.059 & -0.072 & 0.186 \\
\hline $\begin{array}{l}\text { Travel to places that are in } \\
\text { fashion }\end{array}$ & 0.835 & 0.880 & 0.738 & 0.122 & 0.023 & 0.213 \\
\hline $\begin{array}{l}\text { Go to comfortable places, with } \\
\text { good hotels and restaurants }\end{array}$ & 0.707 & 0.257 & 0.708 & 0.268 & 0.082 & 0.049 \\
\hline
\end{tabular}


Table 2 Factor analysis of motivations (continued)

\begin{tabular}{lcccccc}
\hline Variables & COM. & MOTI1 & MOTI2 & MOTI3 & MOTI4 & MOTI5 \\
\hline Relieve stress and tensions & 0.790 & 0.022 & -0.012 & 0.884 & -0.026 & -0.082 \\
Escape from daily routine & 0.784 & 0.052 & 0.052 & 0.867 & 0.152 & 0.058 \\
Rest and relaxation & 0.667 & 0.054 & 0.131 & 0.792 & 0.122 & -0.072 \\
Adventure and fun & 0.850 & 0.133 & 0.141 & -0.073 & 0.870 & 0.223 \\
Do exciting things & 0.825 & 0.163 & 0.222 & 0.176 & 0.827 & 0.186 \\
Fun and entertainment & 0.684 & 0.154 & 0.224 & 0.120 & 0.771 & 0.045 \\
Make new friends & 0.862 & 0.129 & 0.232 & 0.011 & 0.242 & 0.856 \\
Interact with other people & 0.862 & 0.241 & 0.254 & 0.059 & 0.161 & 0.843 \\
& & & & & & \\
Eigenvalue & & 5.873 & 2.304 & 1.714 & 1.213 & 1.003 \\
\% partial explained variance & & 18.477 & 16.176 & 15.003 & 14.813 & 11.201 \\
\% total explained variance & 75.670 & & & & & \\
Cronbach's alpha factor & & 0.8636 & 0.8218 & 0.8091 & 0.8625 & 0.8519 \\
Cronbach's alpha total & 0.8835 & & & & & \\
Suitability tests: & & & & & & \\
KMO: & 0.841 & & & & & \\
Bartlett's sphericity: & $2,604.754$ & & & & & \\
Significance: & 0.000 & & & & & \\
\hline
\end{tabular}

The first factor encompasses all aspects related to cultural motivations, with the novelty factor being the least representative. In the factor of status and social influence, the weight is evenly distributed amongst the four items. The third factor refers to relaxation and escape, whilst the fourth factor includes adventure and fun, with high loads in all of the elements. The last dimension includes social interaction, with high weights in both items. The dimensions obtained largely coincide with those initially proposed in the literature.

Regarding the reliability of the scale, both on an overall level and on the different motivational factors, the levels are satisfactory, with Cronbach's alpha values ranging from 0.81 to 0.86 .

\subsection{Factors of cognitive accommodation image that determine the overall image}

A logistic regression was used to determine which of the seven factors obtained really define the overall, holistic image of a non-hotel establishment perceived by tourists after a direct experience. Following Ekinci et al. (2003), a new dichotic variable was created based on the average value, which enabled the creation of two groups of tourists:

1 those who evaluated accommodation image below average

2 those who evaluated it above average.

The decision to create a dichotic variable is supported by the goal of this study (to differentiate between a positive or negative image) and the record of previous similar 
studies following this methodological criteria. The first group contained $46.6 \%$ of the sample and the second the remaining 53.4\%.

A logistic regression was run using that dichotic variable as the dependent variable and the previously described seven factors of establishment image as the independent variables. The results of that analysis (see Table 3 ) reveal that the factors that best define overall accommodation image are 'personnel and cleanliness', 'kitchen', 'outdoor areas', and 'primary services'. That regression shows that $49.2 \%$ of the individuals in the first group and $70.0 \%$ in the second are correctly classified or that $60.3 \%$ of the total is correctly classified.

Table 3 Logistic regression of overall accommodation image depending on the dimensions of cognitive accommodation image

\begin{tabular}{lcccc}
\hline Dimension & $B$ & $\operatorname{Exp}(B)$ & Wald & Sig. \\
\hline Secondary services & 0.016 & 1.016 & 0.015 & 0.902 \\
Food and beverage & 0.120 & 1.128 & 0.788 & 0.375 \\
Personnel and cleanliness & 0.366 & 1.442 & 6.734 & 0.009 \\
Kitchen & 0.409 & 1.506 & 9.143 & 0.002 \\
Outdoor areas & 0.298 & 1.347 & 5.084 & 0.024 \\
Primary services & 0.285 & 1.330 & 4.558 & 0.033 \\
Price & 0.096 & 1.100 & 0.509 & 0.476 \\
Case classification & & & -2 log likelihood: 335.021 \\
\% with accommodation image below the average & 49.2 & & \\
\% with accommodation image above the average & 70.0 & & \\
\% total of cases & 60.3 & & \\
\hline
\end{tabular}

Therefore, the dimensions of cognitive non-hotel accommodation image differ in their importance to explain overall accommodation image with the dimensions of price, food and beverage, and secondary services being of little importance in the formation of that overall image.

\subsection{Influence of motivations on cognitive accommodation image}

To analyse the influence of motivations on cognitive accommodation image, we identified groups of tourists based on their main motivations when they chose Gran Canaria as a travel destination. For this purpose, we used a k-means clustering because hierarchical methods are not amenable to analysing large samples (Hair et al., 1998). Specifically, the approach used for assigning tourists to one of the clusters was an optimisation procedure because such procedure switches the object to the more similar (closer) cluster. The results of the cluster analysis (see Table 4) show that the most satisfactory solution divided individuals into two groups:

1 one group could be labelled as 'fun and prestige' (cluster 1)

2 the other 'relaxation, knowledge, and social interaction' (cluster 2).

This solution of two clusters was the most satisfactory because for the three-group or the four-group solutions, the cluster sizes were quite similar to those from the two-group solution, varying in size at the most by only few observations. 
Table 4 Characteristics of tourist clusters according to motivations

\begin{tabular}{lcc}
\hline Motivation & \multicolumn{2}{c}{ Final clusters } \\
\cline { 2 - 3 } factors & Cluster 1 & Cluster 2 \\
\hline Knowledge & -0.625 & 0.303 \\
Prestige & 0.221 & -0.308 \\
Relaxation & -0.446 & 0.410 \\
Fun & 0.338 & -0.295 \\
Social interaction & -0.428 & 0.294 \\
Cluster size & 90 & 112 \\
\hline
\end{tabular}

Following Hair et al.'s (1987) recommendations, seven additive scales were created, one for each dimension of accommodation image, using the arithmetic average of the high loading variables of each dimension. The reasons for using the additive scales are the following:

1 it avoids the measurement error in all of the observed variables that are otherwise masked, for instance, in correlations or when comparing groups

2 it can represent multiple aspects of a concept in a single measure

3 it facilitates the interpretation of the results.

Table 5 Mean differences between the two groups of tourists according to motivations

\begin{tabular}{lccccc}
\hline Dimensions & Cluster & Mean & S.D. & $t$ & $P$ \\
\hline Secondary services & Cluster 1 & 3.990 & 1.562 & 2.731 & 0.007 \\
& Cluster 2 & 3.471 & 1.561 & & \\
Food and beverage & Cluster 1 & 5.849 & 1.088 & 3.986 & 0.000 \\
& Cluster 2 & 5.266 & 1.368 & & \\
Personnel and & Cluster 1 & 6.071 & 0.777 & 3.104 & 0.002 \\
cleanliness & Cluster 2 & 5.737 & 1.027 & & \\
Kitchen & Cluster 1 & 5.185 & 1.214 & 2.957 & 0.003 \\
\multirow{2}{*}{ Outdoor areas } & Cluster 2 & 4.745 & 1.275 & & \\
\multirow{2}{*}{ Primary services } & Cluster 1 & 4.377 & 1.403 & 2.885 & 0.004 \\
& Cluster 2 & 3.862 & 1.505 & & \\
Price & Cluster 1 & 5.237 & 1.122 & 2.304 & 0.022 \\
& Cluster 2 & 4.906 & 1.267 & & \\
\hline & Cluster 1 & 5.349 & 1.269 & 3.081 & 0.002 \\
\hline
\end{tabular}

A test for independent samples was conducted to determine whether there were significant differences between the two groups of tourist clusters in the dimensions of cognitive accommodation image. The results (see Table 5) show there are significant differences between both groups of tourists, as all significance levels are below 0.03 . Tourists who visit Gran Canaria and looked for fun and prestige (cluster 1) have higher 
values in all dimensions of accommodation image than those driven by relaxation, knowledge, and social interaction (cluster 2). The dimensions with lower values for both groups are those of secondary services and outdoor areas, being the priority in designing improvements by the accommodation companies to improve the overall image. However, the dimensions better evaluated are those of personnel and cleanliness and also food and beverage. The rest of the dimensions received a medium-positive evaluation.

\section{Conclusions and research implications}

The number of studies on accommodation image is scarce, and in the case of non-hotel accommodation, image research is even more limited. Despite this fact, this study analysed the literature on tourism and hospitality related to the accommodation product and proposed the following:

1 a measurement scale and some theoretical dimensions of the cognitive image of non-hotel accommodation

2 an analysis of how motivations influence cognitive accommodation image.

The study used a multicultural sample of tourists, and the empirical results show the multidimensional nature of non-hotel accommodation image, which comprises seven factors: 'secondary services', 'food and beverage', 'personnel and cleanliness', 'kitchen', 'outdoor areas', 'primary services', and 'price'. The study also empirically shows that some dimensions are more important than others in the formation of overall accommodation image - namely, 'personnel and cleanliness', 'kitchen', 'outdoor areas', and 'primary services'.

Regarding the influence of motivations on cognitive accommodation image, there are significant differences between the two identified motivational clusters. Tourists motivated by fun and prestige (cluster 1) have higher values in all of the dimensions of accommodation image than tourists driven by relaxation, knowledge, and social interaction (cluster 2).

The results have significant academic and practical implications. On the one hand, the proposed scale shows good measures of fit, which suggests that it is applicable in other tourist destinations to analyse non-hotel accommodation. This enables the conduct of comparative studies in different types of accommodations and geographical areas by simply adapting the attributes to the peculiarities of the accommodation. The results also suggest some differences amongst the several image dimensions in explaining the overall image perceived by the tourists. In any case, further studies are necessary to confirm the dimensions that form the image of non-hotel accommodation and their importance. This study has started a new line of investigation on how tourists' motivations affect accommodation image.

On the other hand, the results enable practitioners to better understand how tourists perceive this type of accommodation image and to identify the factors that ultimately influence the final image, thereby prioritising the actions to be taken to improve their management. For instance,

1 housekeeping personnel and their performance play an important role in the formation of the overall image, and thus, specific training of the staff is advisable 
2 the kitchen and its equipment are key elements in the design of this accommodation type

3 the main services of non-hotel accommodation in sun and beach destinations include reception, minimarket, and swimming pool

4 the general image of the establishment is mainly based on the outdoor areas (e.g., gardens).

Similarly, tourists' motivations should be taken into account when attempting to improve the service and the projected image of the accommodation.

Moreover, the results are also useful for the DMOs. By understanding perceived accommodation image and its dimensions as well as how these dimensions affect the formation of the overall image, public institutions can improve the product and project the desired image to its target markets. The importance of these findings becomes clear when we consider that destination image depends, to a great extent, on accommodation image.

Finally, our study has some limitations that should be addressed by future research. From a conceptual point of view, affective image has not been included in this research nor have different factors that might affect the image formation process, such as the customers' personal characteristics and the specific characteristics of the accommodation itself. In this respect, further research should consider these aspects when developing a general model of accommodation image formation. More research is required into the tourist's perception of different theoretical concepts (satisfaction, quality, and image), as well as into the dimensions of those concepts and their relationships. From a methodological perspective, this study has some limitations that affect the evaluation and generalisation of the findings, such as the transversal nature of this study, which recommends longitudinal studies that address the process of image formation and changes in the image and their relationships. Furthermore, instead of creating a dichotic variable when analysing an image, it can be enhanced by identifying different levels of image perception. Finally, the generalisation of the findings is yet another limitation, as the results can only be generalised to the population of the sample and to the tourist destination of Gran Canaria. Thus, it would be advisable to replicate this research in other destinations adding new research questions and especially considering a qualitative approach. Future research should also consider different types of accommodation (hotel, time-sharing, etc.). Another aspect worthy of investigation is whether information sources influence accommodation image, especially bearing in mind the impact of new factors such as social media. These information sources should be integrated in the research, and developing content analysis could be a useful methodology to do so. Future studies could improve the understanding of the dimensions of different accommodation types and destinations and test whether the different dimensions affect the formation of the overall image.

\section{Acknowledgements}

The authors gratefully acknowledge financial support by the Spanish Ministry of Science and Technology (Projects ECO2012-35112, ECO2009-12629, and ECO2008-06148) and by the Agencia Canaria de Investigación (Projects SolSub C200801000381 and PI2007/040). 


\section{References}

Andriotis, K. (2008) 'Integrated resort development: the case of Cavo Sidero, Crete', Journal of Sustainable Tourism, Vol. 16 No. 4, pp.428-444.

Bailey, M. (1995) 'Hong Kong', EIU International Tourism Reports, Vol. 4, pp.5-21.

Baloglu, S. (1997) 'The relationship between destination images and sociodemographic and trip characteristics of international travellers', Journal of Vacation Marketing, Vol. 3, No. 3, pp.221-233.

Baloglu, S. and Mangaloglu, M. (2001) 'Tourism destination images of Turkey, Egypt, Greece, and Italy as perceived by US-based tour operators and travel agents', Tourism Management, Vol. 22, pp.1-9.

Baloglu, S. and Mccleary, K.W. (1999) 'A model of destination image formation', Annals of Tourism Research, Vol. 26 No. 1, pp.868-897.

Barsky, J. and Labagh, R. (1992) 'A strategy for customer satisfaction', The Cornell Hotel and Restaurant Administration Quarterly, Vol. 35, No. 3, pp.32-40.

Barsky, J. and Nash, L. (2002) 'Evoking emotion: affective keys to hotel loyalty', Cornell Hotel and Restaurant Administration Quarterly, February, pp.39-46.

Beerli, P.A. and Martín, J.D. (2004) 'Factors influencing destination image', Annals of Tourism Research, Vol. 31, No. 3, pp.657-681.

Bhote, K.R. (1996) Beyond Customer Satisfaction to Customer Loyalty, AMA Management Briefing, New York.

Bowen, J.T. and Sparks, B.A. (1998) 'Hospitality marketing research: a content analysis and implications for future research', International Journal of Hospitality Management, Vol. 17, No. 2, pp.125-144.

Brownell, J. (2003) 'Applied research in managerial communication: the critical link between knowledge and practice', Cornell Hotel and Restaurant Administration Quarterly, April, pp.39-49.

Callan, R.J. (1994) 'Development of a frame for the determination of attributes used for hotel selection - indications from focus group and in-depth interviews', Hospitality Research Journal, Vol. 18, No. 2, pp.53-74.

Chen, C.F. and Chen, F.S. (2010) 'Experience quality, perceived value, satisfaction and behavioral intentions for heritage tourists', Tourism Management, Vol. 31, No. 1, pp.29-35.

Chen, J.S. and Hsu, C.H. (2000) 'Measurement of Korean tourists' perceived images of overseas destinations', Journal of Travel Research, Vol. 38, pp.411-416.

Chen, J.S., Ekinci, Y., Riley, M., Yoon, Y. and Tjelflaat, S. (2001) 'What do Norwegians think of US lodging services?', International Journal of Contemporary Hospitality Management, Vol. 13, No. 6, pp.280-284.

Chen, P.J. and Kerstetter, D.L. (1999) 'International students' image of rural Pennsylvania as a travel destination', Journal of Travel Research, Vol. 37, pp.256-266.

Choi, T.Y. and Chu, R. (2001) 'Determinants of hotel guests' satisfaction and repeat patronage in the Hong Kong hotel industry', Hospitality Management, Vol. 20, pp.277-297.

Choi, T.Y. and Chu, R.K.S. (1999) 'Consumer perceptions of the quality of services in three hotel categories in Hong Kong', Journal of Vacation Marketing, Vol. 5, No. 2, pp.176-189.

Chu, R. (2002) 'Stated-importance versus derived-importance customer satisfaction measurement', Journal of Services Marketing, Vol. 16, No. 4, pp.285-301.

Chu, R.K.S. and Choi, T. (2000) 'An importance-performance analysis of hotel selection factors in the Hong Kong hotel industry: a comparison of business and leisure travellers', Tourism management, Vol. 21, pp.363-377.

Correia, A., Moital, M., Nuno, O. and Ferreira, C. (2009) 'Multidimensional segmentation of gastronomic tourists based on motivation and satisfaction', International Journal of Tourism Policy, Vol. 2, No. 1-2, pp.37-57. 
Crompton, J.L. (1979) 'Motivations for pleasure vacation', Annals of Tourism Research, Vol. 6, pp.408-424.

Dann, G.M. (1996) The Language of Tourism: A Sociolinguistic Perspective, Cab International., Wallingford.

Dann, G. (1981) 'Tourist motivation an appraisal', Annals of Tourism Research, Vol. 8, No. 2, pp.187-219.

Dann, G. (1977) 'Anomie, ego-enhancement and tourism', Annals of Tourism Research, Vol. 4, No. 4, pp.184-194.

Dubais, B. (1999) Comportamiento del Consumidor, Prentice Hall, Madrid.

Dubé, L. and Renaghan, L.M. (1999) 'Building customer loyalty', Cornell Hotel and Restaurant Administration Quarterly, Vol. 40, No. 5, pp.78-88.

Dubé, L. and Renaghan, L.M. (2000) 'Creating visible customer value', Cornell Hotel and Restaurant Administration Quarterly, Vol. 41, No. 1, pp.62-72.

Echtner, C.M. and Ritchie, J.R. (1991) 'The meaning and measurement of destination image', The Journal of Tourism Studies, Vol. 2, No. 2, pp.2-12.

Echtner, C.M. and Ritchie, J.R. (1993) 'The measurement of destination image: an empirical assessment', Journal of Travel Research, Vol. 31, pp.3-13.

Ekinci, Y. (2002) 'A review of theoretical debates on the measurement of service quality: implications for hospitality research', Journal of Hospitality \& Tourism Research, Vol. 26, No. 3, pp.199-216.

Ekinci, Y., Prokopaki, P. and Cobanoglu, C. (2003) 'Service quality in Cretan accommodationss: marketing strategies for the UK holiday market', Hospitality Management, Vol. 22, pp.47-66.

Ekinci, Y., Riley, M. and Fife-Schaw, C. (1998) 'Which school of thought? The dimensions of resort hotel quality', International Journal of Contemporary Hospitality Management, Vol. 10, No.2, pp.63-67.

Esper, F.S. and Rateike, J.A. (2010) 'Tourism destination image and motivations: the Spanish perspective of Mexico', Journal of Travel \& Tourism Marketing, Vol. 27, No. 4, pp.349-360

Fakeye, P.C. and Crompton, J.L. (1991) 'Image differences between prospective, first-time, and repeat visitors to the Lower Rio Grande Valley', Journal of Travel Research, Vol. 30, No. 2, pp.10-16.

Fodness, D. (1994) 'Measuring tourist motivation', Annals of Tourism Research, Vol. 2, No. 1, pp.551-581.

Getty, J.M. and Thompson, K.N. (1994) 'A procedure for scaling perceptions of lodging quality', Hospitality Research Journal, Vol. 18, No. 2, pp.75-96.

Gnoth, J. (1997) 'Tourism motivation and expectation formation', Annals of Tourism Research, Vol. 24, No. 2, pp.283-304.

Goossens, C. (2000) 'Tourism information and pleasure motivation', Annals of Tourism Research, Vol. 27, No. 2, pp.301-321.

Gray, H.P. (1979) International Travel: International Trade, Heath Lexington Books, Lexington, MA.

Hair, J.E., Jr., Anderson, R.E., Tatham, R.L. and Black, W.C. (1998) Multivariate Data Analysis, 5th ed., New Jersey, Prentice Hall, Inc.

Hair, J.K., Anderson, R.E., Tatham, T.L. and Blanc, W.C. (1987) Análisis Multivariante, Prentice Hall, Madrid.

Headley, D.E. and Myller, S.J. (1993) 'Measuring service quality and its relationship to future consumer behavior', Journal of Health Care Marketing, Vol. 13, No. 4, pp.32-41.

Heide, M., Gronhaug, K. and Engset, M.G. (1999) 'Industry specific measurement of consumer satisfaction: experiences from the business traveling industry', International Journal of Hospitality Management, Vol. 18, No. 2, pp.201-213. 
Heung, V.C.S. (2000) 'Satisfaction levels of mainland Chinese travelers with Hong Kong hotel services', International Journal of Contemporary Hospitality Management, Vol. 12, No. 5, pp.308-315.

Heung, V.C.S., Mok, C. and Kwan, A. (1996) 'Brand loyalty in hotels: an exploratory study of overseas visitors to Hong Kong', Australian Journal of Hospitality Management, Vol. 3, No.1, pp.1-11.

Hu, Y. and Ritchie, J.R.B. (1993) 'Measuring destination attractiveness: a contextual approach', Journal of Travel Research, Vol. 32, pp.25-34.

Huang, R., Busby, G. and Bosdou, C. (2009) 'The first Plymouth: pictorial element and destination image', International Journal of Tourism Policy, Vol. 2, No. 4, pp.246-261.

Hunt, J.D. (1975) 'Images as a factor in tourism development', Journal of Travel Research, Vol. 13, pp.3-7.

Kandampully, J. and Suhartanto, D. (2000) 'Customer loyalty in the hotel industry: the role of customer satisfaction and image', International Journal of Contemporary Hospitality Management, Vol. 12, No. 6, pp.346-351.

Kandampully, J. and Suhartanto, D. (2003) 'The role of customer satisfaction and image in gaining customer loyalty in the hotel industry', Journal of Hospitality \& Leisure Marketing, Vol. 10, Nos. 1/2, pp.3-25.

Laroche, M. and Parsa, H.G. (2000) 'Brand management in hospitality: an empirical test of the Brisoux-Laroche model', Journal of Hospitality \& Tourism Research, Vol. 24, No. 2, pp.200-222.

LeBlanc, G. and Nguyen, N. (1996) 'An examination of the factors that signal hotel image to travelers', Journal of Vacation Marketing, Vol. 3, No. 1, pp.32-42.

Lee, T.H. (2009) 'A structural model to examine how destination image, attitude, and motivation affect the future behavior of tourists', Leisure Sciences, Vol. 31, No. 3, pp.215-236.

Lewis, R.C. (1984) 'The basis of hotel selection', Cornell Hotel and Restaurant Administration Quarterly, Vol. 25, pp.54-59.

Lewis, R.C. (1985) 'Getting the most from marketing research (Part V) predicting hotel choice: the factors underlying perception', The Cornell Hotel and Restaurant Administration Quarterly, Vol. 25, No. 4, pp. 82-96.

Litaca, J.W., Mowen, J.C. and Chakraborty, G. (1995) 'Diagnosing perceived quality: the medical service channel', Journal of Health Care Marketing, Vol. 15, No. 4, pp.42-49.

Lockwood, A., Gummesson, A., Hubrecht, J. and Senior, M. (1992) 'Developing and maintaining a strategy for service quality', in R. Teare, and M. Olsen, (Eds.): International Hospitality Management Corporate Strategy in Practice, Pitman, London, pp.312-339.

Mackay, K.J. and Crompton, J.L. (1990) 'Measuring the quality of recreation services', Journal of Park and Recreation Administration, Vol. 8, No. 3, pp.47-56.

Mansfeld, Y. (1992) 'From motivation to actual travel', Annals of Tourism Research, Vol. 19, No. 3, pp.399-419.

Mazanec, J.A. (1995) 'Positioning analysis with self-organizing maps: an exploratory study on luxury hotels', Cornell H.R.A. Quarterly, Vol. 36, No. 6, pp.80-95.

Mei, A.W.O., Dean, A.M. and White, C.J. (1999) 'Analyzing service quality in the hospitality industry’, Managing Service Quality, Vol. 9, No. 2, pp.136-143.

Milman, A. and Pizan, A. (1995) 'The role of awareness and familiarity with a destination: the Central Florida case', Journal of Travel Research, Vol. 33, No. 3, pp.21-27.

Min, H. and Min, H. (1996) 'Competitive benchmarking of Korean luxury hotels using the analytic hierarchy process and competitive gap analysis', Journal of Services Marketing, Vol. 10, No. 3, pp.58-72.

Min, H., Min, H. and Chung, K. (2002) 'Dynamic benchmarking of hotel service quality', Journal of Services Marketing, Vol. 16, No. 4, pp.302-321. 
Morgan, M.S. and Dev, C.S. (1994) 'Defining competitive sets of hotel brands through analysis of customer bran switching', Journal of Hospitality \& Leisure Marketing, Vol. 2, No. 2, pp.57-91.

Morrison, A. (2002) 'Hospitality research: a pause for reflection', International Journal of Tourism Research, Vol. 4, No. 3, pp.161-169.

Moutinho, L. (1987) 'Consumer behavior in tourism', European Journal of Marketing, Vol. 21, No. 10 , pp.5-44.

Murphy, P., Pritchard, M. and Smith, B. (2000) 'The destination product and its impact on traveler perceptions', Tourism Management, Vol. 21, No. 1, pp.43-52.

Okumus, A. and Yasin, B. (2009) 'Images of Italy, France and Morocco as tourist destinations', International Journal of Tourism Policy, Vol. 2, No. 4, pp.306-318.

Ostrowsky, P.L., O'brien, T.V. and Gordon, G.L. (1993) 'Service quality and customer satisfaction in the commercial airline industry', Journal of Travel Research, Vol. 32, No. 2, pp.16-24.

Pearce, P.L. (1982) 'Perceived changes in holiday destinations', Annals of Tourism Research, Vol. 9, No. 2, pp.145-164.

Pearce, P.L. (1993) 'Defining tourism study as a specialism: a justification and implications', Teoros International, Vol. 1, No. 1, pp.25-32.

Piccoli, G. and Wagner, E.L. (2003) 'The value of academic research', Cornell Hotel and Restaurant Administration Quarterly, Vol. 44, No. 2, pp.29-38.

Pizam, A. and Milman A. (1993) 'Predicting satisfaction among first time visitors to a destination by using the expectancy disconfirmation theory', International Journal of Hospitality Management, Vol. 12, No. 2, pp.197-209.

Pyo, S., Mihalik, B.J. and Uysal, M. (1989) 'Attraction attributes and motivations: a canonical correlation analysis', Annals of Tourism Research, Vol. 16, No. 2, pp.277-283.

Qu, H. and Tsang, N. (1998) 'Service quality gap in China's hotel industry: a study of tourist perceptions and expectations', Journal of Hospitality \& Tourism Research, Vol. 22, No. 3, pp.252-267.

Roth, M.S. (1995) 'The effects of culture and socioeconomics on the performance of global brand image strategies', Journal of Marketing Research, Vol. 32, No. 2, pp.163-175.

San Martin, H. and Rodríguez del Bosque, I.A. (2008) 'Exploring the cognitive - affective nature of destination image and the role of psychological factors in its formation', Tourism Management, Vol. 29, No. 2, pp.263-277.

Taylor, S.A. and Cronin, J.J. (1994) 'Modeling patient satisfaction and service quality', Journal of Health Care Marketing, Vol. 14, No. 1, pp.34-44.

Tsang, N. and Qu, H. (2000) 'Service quality in China's hotel industry: a perspective from tourists and hotel managers', International Journal of Contemporary Hospitality Management, Vol. 12, No. 5, pp.316-326.

Valls, J.F. (1996) Las claves del mercado turístico: cómo competir en el nuevo entorno, Deusto, Bilbao.

Wagner, O., Peters, M. and Schuckert, M. R. (2009) 'Internal branding in tourism destinations: Implications for tourism policy and research', International Journal of Tourism Policy, Vol. 2, No. 4, pp.274-288.

Walmsley, D.J. and Jenkins, J.M. (1993) 'Appraisive images of tourist areas: application of personal construct', Australian Geographer, Vol. 24, No. 2, pp.1-13.

Yucelt, U. and Marcella, M. (1995) 'Perception of service quality in the U.S. lodging industry', Journal of Hospitality \& Leisure Marketing, Vol. 3, No. 2, pp.45-70.

Zeithaml, V.A. and Bitner, M.J. (1996) Services Marketing, McGraw-Hill International Editions, NY. 


\section{Appendix}

Dimension and attributes determining the perceived image of the non-hotel accommodation

\begin{tabular}{|c|c|c|}
\hline Establishment in general & Primary services & Secondary services \\
\hline $\begin{array}{l}\text { - Location } \\
\text { - Security of the customer } \\
\text { and belongings } \\
\text { - Peace and quiet } \\
\text { - Cleanliness } \\
\text { - Corporate reputation and } \\
\text { identity } \\
\text { - Size } \\
\text { - Design and architecture }\end{array}$ & $\begin{array}{l}\text { - Reception service } \\
\text { - Mini-market } \\
\text { - Swimming pool } \\
\text { - Solarium } \\
\text { - Gardens and recreation } \\
\text { areas }\end{array}$ & $\begin{array}{l}\text { - Entertainment services } \\
\text { - Night life } \\
\text { - Children's services (play } \\
\text { area, baby-sitting, special } \\
\text { menus) } \\
\text { - Health club, sauna, } \\
\text { massage } \\
\text { - Sports offering (racquet } \\
\text { sports, courts, gym, etc.) } \\
\text { - Contracting external } \\
\text { services (excursions, car } \\
\text { hire) } \\
\text { - Parking }\end{array}$ \\
\hline Accommodation unit & Service personnel & Price \\
\hline $\begin{array}{l}\text { - Maintenance } \\
\text { - Furniture } \\
\text { - Spaciousness } \\
\text { - Cleanliness and change of } \\
\text { bed-linen } \\
\text { - Views } \\
\text { - Individual terrace and/or } \\
\text { garden area } \\
\text { - Comfort of bed } \\
\text { - Kitchen in general } \\
\text { - Kitchen equipment } \\
\text { (electric appliances) } \\
\text { - Bathroom in general } \\
\text { - bathroom cleanliness and } \\
\text { towel change } \\
\text { - spaciousness } \\
\text { - accessories (hair-drier, } \\
\text { etc.) } \\
\text { - complements (shampoo, } \\
\text { gel, etc.) } \\
\text { - Complements } \\
\text { - air conditioning } \\
\text { - satellite TV }\end{array}$ & $\begin{array}{l}\text { - Speed } \\
\text { - Efficiency } \\
\text { - Sympathy } \\
\text { - Professionalism } \\
\text { - Tendency to help } \\
\text { - Knowledge of languages } \\
\text { - Willing service } \\
\text { - Appearance of personnel }\end{array}$ & $\begin{array}{l}\text { - Fair or low price } \\
\text { - Possibility of discounts } \\
\text { - Advantages for regular } \\
\text { customers } \\
\text { - Free complements }\end{array}$ \\
\hline
\end{tabular}


Dimension and attributes determining the perceived image of the non-hotel accommodation (continued)

Food and beverage offering (where applicable)

- $\mathrm{F}+\mathrm{B}$ centers available

- Price of food and beverage offering

- Food and beverage quality

- Food hygiene

- Varied food and beverage offering 